4. Giesbrecht GG, Bristow GK, Uin A, Ready AE, Jones RA. Effectiveness of three field treatments for induced mild (33.0 degrees C) hypothermia. J Appl Physiol. 1987;63:2375-2379.

5. Giesbrecht GG. Cold stress, near drowning and accidental hypothermia: a review. Aviat Space Environ Med. 2000;71: 733-752.

6. Mittleman KD, Mekjavic IB. Effect of occluded venous return on core temperature during cold water immersion. J Appl Physiol. 1988;65:2709-2713.

7. Giesbrecht GG, Bristow GK. A second postcooling afterdrop: more evidence for a convective mechanism. J Appl Physiol. 1992;73:1253-1258.

\section{Sidecountry and Backcountry Rescues}

\section{To the Editor:}

It is with great interest that I read Dr Van Tilburg's editorial regarding, "Sidecountry Rescue-Who Should Respond to Ski Resort Out-of-Bounds Rescues?" I agree with his conclusions and implementation of recommendations; however, I cannot overstress the geographical generalities with which sidecountry and backcountry skiing actually pose problems.

The 4 major ski resorts in Arctic Scandinavia, Abisko, Björkliden, Riksgränsen, and Narvik owe, in many cases, their entire existence to sidecountry and backcountry access. Indeed, the actual groomed areas are passable, but in many cases marginal at best. Trail maps readily mark areas that are not patrolled but commonly known to be popular "rides." The Arctic location, combined with lack of foliage and very cold powdered snow, is impossible to resist. Because of the rough weather conditions and remoteness, at times these locations are completely isolated from the outside world. Transport by road, helicopter, or rail is impossible. It is the resort-employed ski patrollers who must act far outside of their basic training.

It is not uncommon for the local ski patrollers' knowledge of the local terrain to far outweigh that of the county and national rescue agencies.

Northern Europe is not yet inundated by lawsuits from the occasional disgruntled family member, so the question of liability coverage is less concerning here. It is widely accepted that the mere existence of these Arctic ski areas and their ease of access to the side- and backcountry make the ski areas liable both inside and outside the ski area boundaries.

My professional experience is limited to Riksgränsen, located on the boarder of Norway and Sweden. The hotel and all resort staff are located on the Swedish side of the international boundary, but some of the groomed runs and sidecountry access traverse the border. All ski patrollers are certified by the Swedish ski area governing body, Svenska Liftanläggningars Organisation (SLAO). Their education is similar to that of their counterparts in North America. Medical training is on par with the North American "First Responder" training, and they are schooled in avalanche control, mountain extrication, mountain rescue, and mass casualty incident control.

The SLAO has begun certifying resort physicians in an attempt to better integrate medical practitioners into the daily operations of the mountain. This education is similar to Advanced Wilderness Life Support and PreHospital Trauma Life Support but is mainly focused on potential medical, surgical, and trauma cases that can arise at a ski resort.

Typically, ski patrol and medical personnel are only staffed to patrol the in-boundary skiing. But as the resort offers heliskiing and is a staging ground for snowmobile and backcountry access, personnel may be called to respond outside the area. While official responsibilities include transporting the victim to the nearest vehicle access point, ski patrollers often receive "field promotions" to nurse the victim, and, in some cases, they are the only medical assistance to the resort physician for several hours. Ski patrollers may be requested to respond to an incident miles away from the ski area; they are picked up and transported by a local tourist operator helicopter.

While these ski patrollers campaign for more education and more compensation for such incident involvement, their employers are less enthusiastic. Training and time off-mountain are seen as economic obstacles causing a degree of disgruntlement: the patrollers feel that their knowledge and training are not being best utilized.

Benjamin Lischner, MD, FAWM
Specialist in Family Medicine
Alléen legesenter, Narvik, Norway

\section{Reference}

1. Van Tilburg C. Sidecountry rescue-who should respond to ski resort out-of-bounds rescues? Wilderness Environ Med. 2010;21:100-102.

\section{Shark and Other Aquatic Predator Attacks on Kayakers}

To the Editor:

The recent report on sea kayaking mishaps in New Zealand significantly adds to our knowledge about the epidemiology and medical aspects of untoward incidents occurring in this increasingly popular sport. ${ }^{1}$ No shark attacks were included among the 50 incidents analyzed by Bailey, ${ }^{1}$ although an attack on a kayaker along Northland's east coast in $2005^{2}$ underscores that there is a 